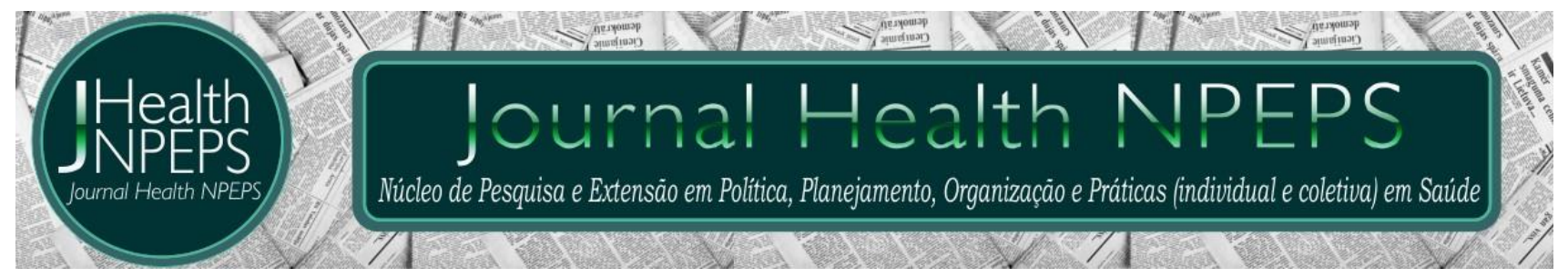

http://dx.doi.org/10.30681/252610104555

ARTIGO ORIGINAL

\title{
Effectiveness of a musculoskeletal injury preventive program in elite beach volleyball players: a retrospective study
}

\section{Efectividad de prevención de lesiones musculoesqueléticas en jugadores de voleibol de playa: un estudio retrospectivo}

\section{Efetividade da prevenção de lesões musculoesqueléticas em atletas de voleibol de praia: um estudo retrospectivo}

\section{Vinícius Soares Santos ${ }^{1}$, Fábio Luís Feitosa Fonseca ${ }^{2}$, Marco Antônio Serquiz ${ }^{3}$, Leticia Amaral Corrêa ${ }^{4}$, Bruno Tirotti Saragiotto ${ }^{5}$, Leandro Alberto Calazans Nogueira ${ }^{6}$}

\begin{abstract}
Objective: to evaluate the effectiveness of a preventive program in athletes of the elite beach volleyball. Method: this is a case series study of seventeen athletes from Brazilian beach volleyball team, between 15 and 20 years. Information about demographic and anthropometric data, and information about hours of practice and number of physiotherapy sessions were obtained in the medical records. The intervention program was performed for 12 weeks, including exercises for the joint complex of the shoulder and lower limbs. The severity of the injury and the functional tests (glenohumeral internal rotation, dynamic valgus, posterior chain flexibility, and vertical jump) was used as outcome measures. The pre and post-intervention outcome were compared. Results: the preventive program showed a low injury rate $(1.37 / 1000$ hours). The functional tests showed contradictory results in post-intervention evaluation. The left shoulder internal rotation (before $=80^{\circ}$ versus after $=86^{\circ}, p=0.024$ ) and posterior chain flexibility (before $=30^{\circ}$ versus after $=33,1^{\circ}, \quad p=0,090$ ) showed improvement. There was no change in dynamic knee valgus (before $p=0.305$, after
\end{abstract}

\footnotetext{
${ }^{1}$ Fisioterapeuta. Mestre. Coordenador da VINCl Fisioterapia. Rio de Janeiro, Rio de Janeiro, Brasil. E-mail: viniciusfisio10@gmail.com ORCID ID: http://orcid.org/0000-0001-7058-6594

${ }^{2}$ Fisioterapeuta. Mestre. Docente do Instituto Federal do Rio de Janeiro (IFRJ). Rio de Janeiro, Rio de Janeiro, Brasil. Email: fabio.fonseca@ifri.edu.br ORCID ID: http://orcid.org/0000-0001-6139-3889.

${ }^{3}$ Fisioterapeuta. Coordenador da VINCl Fisioterapia. Rio de Janeiro, Rio de Janeiro, Brasil. E-mail: ftmarcoserquiz@gmail.com ORCID ID: https://orcid.org/0000-0003-0160-1855

${ }^{4}$ Fisioterapeuta. Mestre. Centro Universitário Augusto Motta (UNISUAM). Rio de Janeiro, Rio de Janeiro, Brasil. E-mail: leticia.amaral@live.com ORCID ID: http://orcid.org/0000-0002-8188-7111.

${ }^{5}$ Fisioterapeuta. Doutor. Docente da Universidade da Cidade de São Paulo - UNICID. São Paulo, São Paulo, Brasil. Email: bruno.saragiotto@sydney.edu.au ORCID ID: http://orcid.org/ 0000-0003-4409-8057.

${ }^{6}$ Fisioterapeuta. Doutor. Docente do Centro Universitário Augusto Motta (UNISUAM); Instituto Federal do Rio de Janeiro. Rio de Janeiro, Rio de Janeiro, Brasil. E-mail: leandro.nogueira@ifri.edu.br ORCID ID: http://orcid.org/00000002-0177-9816 Autor para correspondência - Endereço: Instituto Federal do Rio de Janeiro, Campus Realengo, Rua Carlos Wenceslau, 343, Realengo. CEP 21715-000, Rio de Janeiro, Rio de Janeiro, Brasil.
}

Este artigo está licenciado sob forma de uma licença Creative Commons Atribuição 4.0 Internacional, que permite uso irrestrito, distribuição e reprodução em qualquer meio, desde que a publicação original seja corretamente citada 
$p=0.894$ ) and vertical jump (before $=300 \mathrm{~cm}$ versus after $=296 \mathrm{~cm}, p=0.12$ ). Conclusion: the preventive program performed showed a low injury rate and the functional tests do not show a significant improvement in post-intervention evaluation.

Descriptors: Primary Prevention; Knee; Musculoskeletal Diseases; Shoulder; Sports.

\section{RESUMEN}

Objetivo: evaluar la efectividad de un programa preventivo en atletas del voleibol de playa de élite. Método: una serie de casos de diecisiete atletas del equipo brasileño de voleibol de playa, entre 15-20 años. Los datos demográficos, antropométricos, la información sobre las horas de práctica y el número de sesiones de fisioterapia se obtuvieron en los registros médicos. El programa de intervención se realizó durante 12 semanas, incluidos ejercicios para el complejo articular del hombro y las extremidades inferiores. La gravedad de la lesión y las pruebas funcionales se utilizaron como medidas de resultado. Se compararon los resultados previos y posteriores a la intervención. Resultados: el programa preventivo mostró una baja tasa de lesiones (1.37/1000 horas). Las pruebas funcionales mostraron resultados contradictorios en la evaluación posterior a la intervención. La rotación interna del hombro izquierdo (antes $=80^{\circ}$, después $=86^{\circ}, p=0.024$ ) y la flexibilidad de la cadena posterior (antes $=30^{\circ}$, después $=33.1^{\circ}, p=0.090$ ) mostraron mejoría. No hubo cambios en el valgo dinámico de la rodilla (antes $p=0.305$, después $p=0.894$ ) y salto vertical (antes $=300 \mathrm{~cm}$, después $=296 \mathrm{~cm}, p=0.12$ ). Conclusión: el programa preventivo realizado mostró una baja tasa de lesiones y las pruebas funcionales no muestran una mejora significativa en la evaluación posterior a la intervención.

Descriptores: Prevención Primaria; Rodilla; Enfermedades Musculoesqueléticas; Hombro; Deportes.

\section{RESUMO}

Objetivo: avaliar a efetividade de um programa preventivo em atletas do voleibol de praia de elite. Método: estudo de série de casos com 17 atletas da equipe brasileira de vôlei de praia, entre 15 e 20 anos. Informações sobre dados demográficos, dados antropométricos e informações sobre horas de prática e número de sessões de fisioterapia foram obtidas nos prontuários médicos. 0 programa de intervenção foi realizado por 12 semanas, incluindo exercícios para o complexo articular do ombro e membros inferiores. A gravidade da lesão e os testes funcionais (rotação interna glenoumeral, valgo dinâmico, flexibilidade da cadeia posterior e salto vertical) foram utilizados como medidas de desfecho. Os resultados pré e pós-intervenção foram comparados. Resultados: o programa preventivo apresentou baixa taxa de lesões $(1,37 / 1000$ horas). Os testes funcionais mostraram resultados contraditórios na avaliação pós-intervenção. A rotação interna do ombro esquerdo (antes $=80^{\circ}$ versus depois $=86^{\circ}$, $p=0,024$ ) e a flexibilidade da cadeia posterior (antes $=30^{\circ}$ versus depois $=33,1^{\circ}, p=0,090$ ) apresentaram melhora. Não houve alteração no valgo dinâmico do joelho (antes $p=0,305$, depois $p=0,894$ ) e salto vertical (antes $=300 \mathrm{~cm}$ versus depois $=296 \mathrm{~cm}, p=0,12$ ). Conclusão: o programa preventivo realizado mostrou baixa taxa de lesões e os testes funcionais não mostram uma melhora significativa na avaliação pós-intervenção.

Descritores: Prevenção Primária; Joelho; Doenças Musculoesqueléticas; Ombro; Esportes. 
INTRODUCTION

Volleyball is one of the most popular sports in the world. Volleyball is the second sport in global popularity and is the only game to compose two different Olympic modalities (volleyball and beach volleyball) ${ }^{1}$. The overall injury incidence found in Olympic beach volleyball was $21 \%$ in $2018^{1}$ and an index of 13 overuse injuries of extremity per 1000 hours of exposure ${ }^{2}$. The knee and shoulder are the most affected segments by acute injuries and repetitive strain, respectively ${ }^{2}$. Despite its growth in the last decades, little research has been done on the pattern of injuries in this sport.

Injuries in beach volleyball are usually related to repetitive movements of jumps and throws. In sports where there are jumps, injuries most commonly affect lower limbs than upper limbs $^{3}$. A misalignment of the lower limbs during jumping is a potential mechanism for non-traumatic injuries in several sports. In beach volleyball, there are more repetitive strain injuries in the shoulder compared to court volleyball due to the smaller number of players that lead to a greater number of services and attacks ${ }^{4}$.
The inadequate technique of sports, previous injuries and the level of competitiveness are risk factors for shoulder injuries of elite athletes ${ }^{5,6}$. The main risk factors for musculoskeletal injury in sports are known. However, the implementation of prevention programs and the use of measuring instruments to reduce the risk of future injuries in athletes are still in initial phase $e^{7,8}$.

An evaluation of the functional level of the athlete has been encouraged because the duration of the time loss is not an appropriate measure of injury severity9. Several reviews have recommended the use of functional tests for the evaluation of athletes $7,8,10$. The step-down test is one of the most used tests during functional evaluation of the lower limb'11. The evaluation of glenohumeral internal rotation and adduction has been recommended to detect possible retraction of the posterior capsule in overhead athletes ${ }^{12}$. Researchers and clinicians highlight the importance of this test to identify the risk of shoulder injuries ${ }^{13}$. In sports, functional tests are considered reliable ${ }^{14}$ and are valuable measures to evaluate prevention programs ${ }^{11}$.

The number of publications related to the prevention of sports 
injuries has increased up to $300 \%$ between 2000 and $2007^{15}$. However, to the best of our knowledge, the prevent programs of sports injuries in athletes of beach volleyball are still scarce in the literature. The prevention of injuries in sports has several benefits, with greater longevity in the activity, greater health of individual, reduction of expenditure and maintenance by as many matches and competitions as possible. There are reports of the use of preventive measures for repetitive knee and shoulder injuries in volleyball players ${ }^{16}$.

The small number of studies related to the prevention of injuries in beach volleyball makes necessary the development and evaluation of prevention programs in elite beach volleyball athletes. Therefore, the aim of this study was to evaluate the effectiveness of a preventive program in athletes of the elite beach volleyball. A preventive program may reduce the risk of musculoskeletal pain and the impact of the injury in the absence from training and match play, leading to an optimization of the athlete's performance. Benefits of a preventive program in elite athletes may be translated to recreational athletes. We hypothesised that: (1) the participants of the present case series would present lower rates of injury incidence compared to previously reported on scientific literature; (2) the postintervention assessment would demonstrate functional improvement.

\section{METHOD}

A case series study was conducted with athletes of the Brazilian national team of beach volleyball. This study was approved by Human Research Ethics Committees of the Federal Institute of Rio de Janeiro (number: 51507415.5.0000.5268).

We used data from the Brazilian Volleyball Confederation, collected at the Centre for Development of Volleyball (CDV) in Rio de Janeiro, Brazil. We included youth athletes (aged between 15 and 20 years old) from the Brazilian Volleyball Team (under-19 and under-21 categories). Athletes who did not complete the training period were not included in the study.

The records selected for this study were extracted from the medical record and assigned a specific number of each person in the project (Specific Personal Number of Project - SPNP). The home institution extracted the contents of the approved data and provided this information to the research team with 
the SPNP. The research team assembled the individual dataset for analysis using the SPNP.

Demographic information (age and gender), anthropometric (weight and height) and information about hours of practice and number of physiotherapy sessions were obtained in the medical records. Evaluations were performed at the beginning and end of the training period (12 weeks). Outcome measures were obtained using injury severity and functional tests. During the period between March and July 2014, a preventive exercise program was performed, consisting of strengthening of hip abductors and external rotators, and stretching of the posterior capsule of the shoulder.

The main outcomes of this study are the injury severity from professional practice and performance in functional tests. The injury severity was classified according to the number of days that the athlete was away from the professional practice during the training period (12 weeks) due to musculoskeletal pain (minimal injury: 13; mild injury: 4-7 days; moderate injury: 8-28 days; several injury: > 28 days) ${ }^{17}$ days. The functional tests were composed of four tests: (1) evaluation of glenohumeral internal rotation performed by a goniometer ${ }^{18}$; (2) evaluation of knee dynamic valgus performed by the step-down test according to Piva et al $^{19}$; (3) vertical jump test performed according to Ziv and Lidor ${ }^{20}$; and (4) flexibility of the posterior chain of lower limbs performed by the Wells' bench according to Mayorga-Vega et $a^{21}$. The functional tests were chosen due to the involvement of variables in volleyball practice and injury-related. All tests were carried out by two physiotherapists with five years of experience in sports rehabilitation.

The intervention period consisted of 12 weeks, 30 sessions in total of the preventive protocol. The preventive program was delivered by $a$ physiotherapist with five years of experience in sports rehabilitation. All procedures were conducted at the Centre for Development of Volleyball (CDV). All athletes performed the same protocol in-group-based approach and this was divided into 3 distinct periods of 4 weeks (period 1, 2, and 3). Each period was composed of three sessions per week in the first three weeks, then one session per week in the fourth week. The three periods were structured as follows:

Period 1 of the preventive 
program.

a) The clam exercise was performed with elastic resistance with two distinct colours, blue and purple, with the participant at side-lying position for $3 \times 15$ repetitions on each side ${ }^{22}$;

b) The stretching of the posterior capsule of the shoulder was performed at 90 degrees of abduction (1 minute for each side) ${ }^{23}$;

c) The athletes were oriented to perform the sumo squat whose keep hands on toes, performs a deep squat and returns to standing position for posterior chain dynamic stretching ( $2 \times 20$ repetitions);

d) Active mobilisation of ankles was performed in which the athlete with the single leg support progressed with the lower limb in the anterior direction to dorsiflexion gain (2x20 repetitions on each side) ${ }^{24}$;

e) Unipodal proprioception in dynadisc was oriented with lower limb in extension (1x1 min on each side) ${ }^{25}$;

f) Bilateral horizontal abduction of the shoulder at $120^{\circ}$ was performed seated at inclined bench to $45^{\circ}$ with a weight of $2 \mathrm{~kg}$ for men and $1 \mathrm{~kg}$ for women (2x15 repetitions) were instructed ${ }^{26}$;

g) Scapular protraction was oriented in closed kinetic chain (CKC) in solo with the elbows flexed $(2 \times 20$ repetitions) ${ }^{27}$;

h) Unipodal squat was performed in declined Smith apparatus emphasising eccentric phase (3 seconds to down and 1 second to up, $2 \times 15$ repetitions on each side) ${ }^{28}$.

Period 2 of the preventive program.

a) Hip abduction in lateral decubitus was performed with a $3 \mathrm{~kg}$ ankle weight $(3 \times 15$ repetitions on each side) ${ }^{29}$;

b) Stretching of the posterior capsule of the shoulder with the athlete lying on the upper limb to be stretched adducted in ventral decubitus (1 minute for each side) 30,31 ;

c) The athletes were oriented to perform the sumo squat whose keep hands on toes, performs a deep squat and 
returns to sitting position for posterior chain dynamic stretching ( $2 \times 20$ repetitions);

d) Active mobilisation of ankles was performed in which the athlete with the single leg support alternating to the lateral and medial directions (2x20 repetitions on each side);

e) Unipodal proprioception in dynadisc performing knee flexion-extension until approximately $30^{\circ}$ of flexion (1x1 min on each side);

f) The bilateral horizontal abduction of the shoulder, the scapular protraction exercise, and the unipodal squat were performed in the same manner of the period 1 .

Period 3 of the preventive program.

a) The clam exercise, the sumo squat, the active mobilisation of ankles, and the unipodal squat were performed similarly to the period 1;

b) The stretching of the posterior capsule of the shoulder was performed at 60 degrees of abduction (1 minute for each side); c) The unipodal proprioception in dynadisc was performed similarly to the period 2;

d) Bilateral horizontal abduction of the shoulder at $120^{\circ}$ was performed on Swiss ball with similar scheme of the period 1 ;

e) Scapular protraction was oriented in closed kinetic chain (CKC) in solo with the elbows supported in $a$ dynadisc ( $2 \times 20$ repetitions);

All data were organised in Microsoft Excel $\circledast$ and analysed with the Statistical Package for the Social Sciences (SPSS, version 22). The characteristics of the participants are presented as means and standard deviations for continuous variables and in absolute values and proportions for categorical variables. Injury incidence was expressed as the number of injuries per 1000 hours of exposure and was calculated using the following equation: [(total of injuries/total of exposure hours)] $x$ 1000. The total of exposure hours included match and training hours. Distribution of data on outcome measures was assessed using the Shapiro-Wilk test. Since the distribution of the variables was non-parametric, the Wilcoxon signed rank test was used for 
the continuous variables. Data were presented in median (interquartile range) for continuous variables. Statistical significance was lower than $5 \%(p<0.05)$.

\section{RESULTS}

Seventeen athletes participated in this study, 9 men and 8 women, with an average experience playing beach volleyball of 1.7 years (Table 1). All included athletes concluded the prevention program and presented the upper and lower right limb as dominant. The study period comprised of 15 weeks with an average of 20 hours of training per week, totalling 300 hours of training. Considering all athletes, there was a total of 5100 hours of beach volleyball training. During the intervention period, a total of 7 injuries occurred, 6 of which were classified as minimum injuries (between 1 and 3 days) and 1 was classified as a mild injury (4 days). The injury incidence was 1.37 / 1000 hours of practice.

Table 1 - Characteristics of the players who participated in the study.

\begin{tabular}{|c|c|}
\hline Variables & $M(S D)$ \\
\hline Age (years) & $17.9(1.20)$ \\
\hline Height (m) & $1.92(0.06)$ \\
\hline Weight (kg) & $82.58(6.46)$ \\
\hline Body Mass Index $\left(\mathrm{kg} / \mathrm{m}^{2}\right)$ & $22.29(2.39)$ \\
\hline Practice time (years) & $1.72(1.33)$ \\
\hline
\end{tabular}

Table 2 - Comparison of functional assessment before and after prevention program in professional beach volleyball players. $(n=17)$

\begin{tabular}{lccc}
\hline \multicolumn{1}{c}{ Variables } & Initial Evaluation & Final Evaluation & $P$ value \\
\hline Right internal rotation (degrees) & $82(27.5)$ & $75(11.0)$ & 0.918 \\
Right external rotation (degrees) & $134(18.0)$ & $144(20.5)$ & 0.477 \\
Left internal rotation (degrees) & $80(17.5)$ & $86(16.5)$ & 0.024 \\
Left external rotation (degrees) & $126(15.0)$ & $132(6.5)$ & 0.877 \\
Right total rotation motion (degrees) & $212(33.0)$ & $212(25.0)$ & 1.000 \\
Left total rotation motion (degrees) & $208(16.5)$ & $216(16)$ & 0.058 \\
Right valgus & $2(1.5)$ & $2(1.5)$ & 0.305 \\
Left valgus & $2(2.0)$ & $2(2.0)$ & 0.894 \\
Reach $(\mathrm{cm})$ & $300(10.0)$ & $296(9.5)$ & 0.120 \\
WELLS' Bench (cm) & $30(11.4)$ & $33.1(7.6)$ & 0.090 \\
\hline
\end{tabular}

Data are presented in median (interquartile range). 
The Wilcoxon signed-rank test showed that the prevention program increased left glenohumeral internal rotation $(Z=-2.252, p=0.024)$. The other outcomes of the study did not show significant differences. Table 2 contains the values related to the 2 evaluations and the respective $p$ values obtained in the Wilcoxon signed-rank test.

\section{DISCUSSION}

The present study analysed the effectiveness of a preventive program by describing the incidence of injury and comparing the injury incidence and the functional performance pre- and postintervention for dynamic valgus, glenohumeral internal rotation, vertical jump and posterior chain flexibility of elite players of beach volleyball. The injury incidence was very low during the intervention period. Also, the findings showed a trend of improvement in the flexibility of the posterior chain and the increase of the range of motion of internal rotation of the glenohumeral on the non-dominant side of the players with the implementation of this prevention program. However, the preventive program did not influence dynamic knee valgus and vertical jump.
Since the sports injuries are presumably impossible to be eliminated, successful prevention strategies reduce the number and severity of injuries ${ }^{32}$. The preventive program implemented in elite beach volleyball players resulted in a minimal incidence of injury (1.37 / 1000 hours) when compared to other sports with elite athletes. Elite players in the European football league showed an injury incidence between 6.4 and 13.8 per 1000 hours of practice, considering the total number of hours in training and play ${ }^{17}$. The same study showed that the lowest rate was registered in the 2007 season in men under 19 years considering only the training (1.5 / 1000 hours).

The age group below the age of 19 years is closer to the athletes of the present study. Younger athletes tend to have lower injury rates. The incidence of injury may vary with modality or with competitiveness. Rugby league athletes have even higher rates (346 / 1000 hours) and should be related to the modality with characteristics of greater physical contact ${ }^{33}$. During the 2nd Youth Olympic Winter Games, an incidence of 9\% was described. Beach volleyball players presented an injury incidence of 3.1 / 1000 hours of practice during a competition period ${ }^{34}$. Therefore, beach 
volleyball has been considered $a$ modality with low injury rates. Our results show an injury rate that is approximately the half described for the modality with the implementation of the preventive program.

The lower injury rate compared to the previous studies may be directly related to the preventive program since the results described in the literature are from observational studies and do not consider the influence of preventive programs. However, athletes performed several physiotherapy sessions during the study period and this approach may have contributed to the low incidence of injury. Probably some benefits were achieved during physiotherapy that was not measured in our study. Thus, we are unsure if the low injury rate occurred from the preventive program, the physiotherapy sessions or a combination of both interventions. Manual therapy manoeuvres reduce pain intensity, promote muscle relaxation, and increase the range of motion. The physiotherapist is included as a member of the technical team of highperformance sports and the use of such an approach is consecrated in the sports field, and it is difficult to compare isolated interventions in specific groups of athletes of the same team. Future studies should address whether combining two or more interventions is superior to a single preventive strategy of reduction of injury in professional athletes.

Despite the low incidence of injury, functional performance did not show significant improvement after the preventive program. The improvement of posterior chain flexibility in our study is in line with a previous study that used an active dynamic stretching program ${ }^{35}$. Our findings showed improvement of the glenohumeral internal rotation of the non-dominant limb and maintenance of the glenohumeral internal rotation range of the dominant limb after the preventive program with the inclusion of the stretching the posterior capsule of the shoulder. There are different strategies of shoulder posterior capsule stretching to increase glenohumeral internal rotation in throwing athletes, including horizontal adduction of the upper limb and passive internal rotation with contralateral limb in lateral decubitus ${ }^{12,36}$, both strategies were adopted in our study. Asymptomatic individuals $^{37}$ and baseball athletes ${ }^{38}$ have already shown improvement of the glenohumeral internal rotation with the technique of stretching the posterior capsule. 
The maintenance of the glenohumeral internal rotation range of motion and the total rotational motion of the dominant shoulder was considered a clinical benefit in our study since there is a tendency to reduce this movement during the training period. Thomas et al. evaluated the glenohumeral adaptations in young women throwing athletes (tennis, volleyball, and swimming) after a season of 12 weeks of competition (same period of our study). The authors observed a decrease in the internal rotation of the shoulder at the end of the season ${ }^{39}$, leading us to believe that a shortening of the posterior capsule occurs after a period of competition. In the period in which they were concentrated, athletes are submitted to a much larger volume of training compared to the volume in their respective training centres, whether in volume and intensity of all volleyball actions. Accordingly, it can be considered of clinical relevance the execution of the stretches discussed in our study.

The other functional tests did not show improvement after the intervention period. Our results are in line with those of the study by Ferber et $a^{40}$, in which even after a program strengthening of hip abductors and extensors, there was no improvement related to the dynamic alignment of the lower limb. The negative findings in the vertical jump observed in the present study are in disagreement with previous reports after the use of plyometric training and muscle strengthening (both performed with our athletes in the intervention period by the physical preparation) ${ }^{41}$. The lack of improvement may be related to the accumulation of volume of jumps because the athletes were in a long period concentrated in training or to the modality to be practised in the sand. Finally, functional improvement should be related to other factors that were not addressed in this preventive program. Despite this fact, functional improvement was not necessary to achieve a positive result in the injury incidence.

The limitations of this study are a few number of participants, limited kits for exercises, and a longer followup period should find higher values of injury incidence compared to described in the present study since prospective studies showed higher rates. Nonetheless, conducting a study with a large number of participants in beach volleyball is more complicated since a team consists of two players. In addition, an individualised program 
according to the initial evaluation of the athlete should reflect better functional results and reduction of the injury incidence. Likewise, specific functional tests related to the exercise prescription may identify better results of the preventive program. Nevertheless, a systematic review ${ }^{42}$ revealed a reduction of injury rates using preventive programs in athletes with no difference between generic and sports-specific injury preventive programs. Therefore, the inclusion of this preventive program has the potential to be applicable to other modalities and to be useful for reducing the injuries from sports practice, since it has used resources accessible to clinical practice.

\section{CONCLUSION}

The preventive program performed by elite players of the Brazilian Beach Volleyball Team evidenced a low injury rate. The functional tests did not present relevant improvement at post-intervention evaluation. New strategies should be implemented to improve the physical performance of the athletes, and new studies to achieve an adequate prevention program to beach volleyball athletes are needed.

\section{REFERENCES}

1. Steffen K, Soligard T, Mountjoy M, Dallo I, Gessara AM, Giuria H, et al. How do the new Olympic sports compare with the traditional Olympic sports? Injury and illness at the 2018 Youth Olympic Summer Games in Buenos Aires, Argentina. Br J Sports Med. 2020; 54(3):168-175.

2. Chéron $C$, Le Scanff $C$, LeboeufYde C. Association between sports type and overuse injuries of extremities in adults: a systematic review. Chiropr Man Therap. 2017; 25:4.

3. Caine DJ, Harmer P, Schiff M. The Encyclopaedia of Sports Medicine: An IOC Medical Commission Publication, Epidemiology of Injury in Olympic Sports. Wiley. 2009.

4. Eerkes K. Volleyball injuries. Curr Sports Med Rep. 2012; 11(5):251256.

5. Saragiotto BT, Di Pierro C, Lopes $A D$. Risk factors and injury prevention in elite athletes: a descriptive study of the opinions 
of physical therapists, doctors and trainers. Braz J Phys Ther. 2014; 18(2):137-143.

6. Cools AM, Maenhout AG, Vanderstukken F, Decleve $P$, Johansson FR, Borms D. The challenge of the sporting shoulder: From injury prevention through sport-specific rehabilitation toward return to play. Ann Phys Rehabil Med. 2020.

7. Hanlon C, Krzak JJ, Prodoehl J, Hall KD. Effect of Injury Prevention Programs on Lower Extremity Performance in Youth Athletes: A Systematic Review. Sports Health. 2020; 12(1):12-22.

8. Lopes TJA, Simic M, Myer GD, Ford KR, Hewett TE, Pappas E. The Effects of Injury Prevention Programs on the Biomechanics of Landing Tasks: A Systematic Review With Meta-analysis. Am J Sports Med. 2018; 46(6):14921499.

9. Bahr R. No injuries, but plenty of pain? On the methodology for recording overuse symptoms in sports. Br J Sports Med. 2009; 43(13):966-972.

10. Paul DJ, Nassis GP. Testing strength and power in soccer players: the application of conventional and traditional methods of assessment. J Strength Cond Res. 2015; 29(6):1748-1758.

11. Cates W, Cavanaugh J. Advances in rehabilitation and performance testing. Clin Sports Med. 2009; 28(1):63-76.

12. Cools AM, Johansson FR, Borms D, Maenhout A. Prevention of shoulder injuries in overhead athletes: a science-based approach. Braz J Phys Ther. 2015; 19(5):331-339.

13. Saccol MF, Almeida GP, Souza VL. Anatomical glenohumeral internal rotation deficit and symmetric rotational strength in male and female young beach volleyball players. J Electromyogr Kinesiol. 2016; 29:121-125.

14. Moran RW, Schneiders AG, Major KM, Sullivan SJ. How reliable are Functional Movement Screening scores? A systematic review of rater reliability. $\mathrm{Br} \mathrm{J}$ Sports Med. 2016; 50(9):527-536.

15. Bahr R, Engebretsen L. Handbook of Sports Medicine and Science, Sports Injury Prevention. Nova Jersey: Wiley; 2011.

16. Bere T, Kruczynski J, Veintimilla $\mathrm{N}$, Hamu Y, Bahr R. Injury risk is low among world-class volleyball 
players: 4-year data from the FIVB Injury Surveillance System. $\mathrm{Br} \mathrm{J}$ Sports Med. 2015; 49(17):11321137.

17. Hägglund $M$, Waldén $M$, Ekstrand J. UEFA injury study--an injury audit of European Championships 2006 to 2008. Br J Sports Med. 2009; 43(7):483-489.

18. Manske R, Wilk KE, Davies G, Ellenbecker $\mathrm{T}$, Reinold $M$. Glenohumeral motion deficits: friend or foe? Int J Sports Phys Ther. 2013; 8(5):537-553.

19. Piva SR, Fitzgerald $K$, Irrgang JJ, Jones S, Hando BR, Browder DA, et al. Reliability of measures of impairments associated with patellofemoral pain syndrome. BMC Musculoskelet Disord. 2006; 7:33.

20. Ziv G, Lidor R. Vertical jump in female and male volleyball players: a review of observational and experimental studies. Scand J Med Sci Sports. 2010; 20(4):556567.

21. Mayorga-Vega D, Merino-Marban $\mathrm{R}$, Manzano-Lagunas J, Blanco $\mathrm{H}$, Viciana J. Effects of a Stretching Development and Maintenance Program on Hamstring Extensibility in Schoolchildren: A
Cluster-Randomized Controlled Trial. J Sports Sci Med. 2016; 15(1):65-74.

22. Selkowitz DM, Beneck GJ, Powers CM. Which exercises target the gluteal muscles while minimizing activation of the tensor fascia lata? Electromyographic assessment using fine-wire electrodes. J Orthop Sports Phys Ther. 2013; 43(2):54-64.

23. Wilk KE, Obma $P$, Simpson $C D$, Cain EL, Dugas JR, Andrews JR. Shoulder injuries in the overhead athlete. J Orthop Sports Phys Ther. 2009; 39(2):38-54.

24. Calatayud J, Martin F, Gargallo P, García-Redondo J, Colado JC, Marín PJ. The validity and reliability of a new instrumented device for measuring ankle dorsiflexion range of motion. Int J Sports Phys Ther. 2015; 10(2):197202.

25. McCriskin BJ, Cameron KL, Orr JD, Waterman BR. Management and prevention of acute and chronic lateral ankle instability in athletic patient populations. World J Orthop. 2015; 6(2):161-171.

26. Reinold MM, Escamilla RF, Wilk KE. Current concepts in the scientific and clinical rationale 
behind exercises for glenohumeral and scapulothoracic musculature. J Orthop Sports Phys Ther. 2009; 39(2):105-117.

27. San Juan JG, Suprak DN, Roach SM, Lyda M. The effects of exercise type and elbow angle on vertical ground reaction force and muscle activity during a push-up plus exercise. BMC Musculoskelet Disord. 2015; 16:23.

28. Rudavsky A, Cook J. Physiotherapy management of patellar tendinopathy (jumper's knee). J Physiother. 2014; 60(3):122-129.

29. Fukuda TY, Rossetto FM, Magalhães E, Bryk FF, Lucareli PR, Carvalho NAA. Short-term effects of hip abductors and lateral rotators strengthening in females with patellofemoral pain syndrome: a randomized controlled clinical trial. J Orthop Sports Phys Ther. 2010; 40(11):736-742.

30. Reinold MM, Gill TJ, Wilk KE, Andrews JR. Current concepts in the evaluation and treatment of the shoulder in overhead throwing athletes, part 2: injury prevention and treatment. Sports Health. 2010; 2(2):101-115.
31. Kibler WB, Kuhn JE, Wilk K, Sciascia A, Moore S, Laudner K, et al. The disabled throwing shoulder: spectrum of pathology10-year update. Arthroscopy. 2013; 29(1):141-161.

32. Emery C, Pasanen K. Current Trends in Sport Injury Prevention. Best Pract Res Clin Rheumatol. 2019; 33(1).

33. Gabbett TJ. Incidence of injury in junior and senior rugby league players. $\quad$ Sports Med. 2004; 34(12):849-859.

34. Bahr R, Reeser JC, Volleyball Fld. Injuries among world-class professional beach volleyball players. The Fédération Internationale de Volleyball beach volleyball injury study. Am J Sports Med. 2003; 31(1):119-125.

35. Ayala F, Sainz de Baranda P, De Ste Croix M, Santonja F. Comparison of active stretching technique in males with normal and limited hamstring flexibility. Phys Ther Sport. 2013; 14(2):98104.

36. Mine K, Nakayama T, Milanese S, Grimmer K. Effectiveness of Stretching on Posterior Shoulder Tightness and Glenohumeral Internal Rotation Deficit: A 
Systematic Review of Randomised Controlled Trials. J Sport Rehabil. 2016.

37. McClure P, Balaicuis J, Heiland D, Broersma ME, Thorndike CK, Wood A. A randomized controlled comparison of stretching procedures for posterior shoulder tightness. J Orthop Sports Phys Ther. 2007; 37(3):108-114.

38. Laudner KG, Sipes RC, Wilson JT. The acute effects of sleeper stretches on shoulder range of motion. J Athl Train. 2008; 43(4):359-363.

39. Thomas SJ, Swanik KA, Swanik C, Huxel KC. Glenohumeral rotation and scapular position adaptations after a single high school female sports season. J Athl Train. 2009; 44(3):230-237.
40. Ferber R, Kendall KD, Farr L. Changes in knee biomechanics after a hip-abductor strengthening protocol for runners with patellofemoral pain syndrome. J Athl Train. 2011; 46(2):142-149.

41. Pereira $A$, Costa $A M$, Santos $P$, Figueiredo $\mathrm{T}$, João PV. Training strategy of explosive strength in young female volleyball players. Medicina (Kaunas). 2015; 51(2):126-131.

42. Mugele $\mathrm{H}$, Plummer A, Steffen K, Stoll J, Mayer F, Müller J. General Versus Sports-Specific Injury Prevention Programs in Athletes: A Systematic Review on the Effect on Injury Rates. PloS One. 2018; 13(10).

Financiamento: Os autores declaram que não houve financiamento.

Conflito de interesses: Os autores declaram não haver conflito de interesses.

Participação dos autores:

- Concepção: Santos VS, Fonseca FLF, Serquiz MA, Corrêa LA, Saragiotto BT, Nogueira LAC.

- Desenvolvimento: Santos VS, Fonseca FLF, Serquiz MA, Corrêa LA, Saragiotto BT, Nogueira LAC.

- Redação e revisão: Santos VS, Fonseca FLF, Serquiz MA, Corrêa LA, Saragiotto BT, Nogueira LAC.

Como citar este artigo: Santos VS, Fonseca FLF, Serquiz MA, Corrêa LA, Saragiotto BT, Nogueira LAC. Effectiveness of a musculoskeletal injury preventive program in elite beach volleyball players: a retrospective study. J Health NPEPS. 2020; 5(2):179-194. 